\title{
Linguistic Imperialism \& Cultural Politics in English Language Teaching World
}

\section{Md Nurul Anwar}

Lecturer in English, Department of English, BGMEA University of Fashion and Technology, Dhaka, Bangladesh anwarengnsu@gmail.com

\begin{abstract}
The article reviews the deeply embedded imperialistic history in the language teaching and learning landscape. It critically looks into two identical articles yet thematically quite disparate angles that reveal the most pressing and talked about concerns around the imperialist institutions since the incipience of the idea of linguistic imperialism as well as subconscious subscriptions to secret following of the colonizers' cultural nuances by non-native teachers and learners through teaching and learning materials made available by the UK and USA. It concentrates its focus on age long topics such as the tendency among no-native learners and teachers towards perfecting and prioritizing phonology, near-native proficiency, and inclusion of native culture in their conversation, teaching, and reading. Finally, the wilful evasion of the admission by non-native speaker teachers and students alike to the consequences of being subtly inculcated into western culture due to the West's strategic launching of discipline like TESOL to silently avoid thewatch of non-native speakers is discussed with much greater profoundness.
\end{abstract}

Keywords: Linguistic imperialism, cultural integrity, and EIL and Native-speakerism

\section{INTRODUCTION}

This essay reviews two near similar articles in the same field of English language teaching. The articles are called Linguistic imperialism, cultural integrity, and EIL and Native Speakerism. Both of the topics deal with various anticipatory implications including the spread of massive supply of text books on English language education by UK and USA and other socio-political and cultural forces that help shape indoctrinations among non-native teachers and students. Among all the highlighted elements in these two papers, phonology, nearnative proficiency and inclusion of native culture in the texts are of foremost priority. Precisely, the second article contains some of the most radical ideas like racism, nationalism and liberalism in western education. It is argued that the native speakerist prejudice is often obscured by the apparent liberalism of 'a nice field like TESOL' (Kubota, 2001, 2002 in Holliday, 2006). The analyses of the two essays are very identical and can be interchangeable, while the first article sheds light on the predictive causes for non-native culture facing decay and suggestions for integration and recognition of non-native culture in English learning academia and the second displays more of the reasons or tools used by the native education enterprises, for instance, liberal education, close monitoring technique and learners' autonomy in the classroom. However, the effect of the research would depend on how empirical it is in reaching the proper targets for substantial data. Finally, this review lies out in sections which include, rationale for choosing them for review, methodology used in those articles, research questions asked, methods and paradigms use for data collection, implications and finally the justification behind valid arguments posed in both articles. Hence, the papers will be put side by side to elicit the commonest points where both the papers agree and disagree and why.

\section{Rationale for Choosing the ARTicles}

The two articles chosen have contextual as well as phenomenal connection to my research interest. These two articles reveal a good deal of fundamental assumptions and display hypothetical understanding of why and how English linguistically plays surreptitious roles in subjugating other cultures in the field of English language 
teaching by using text-book materials. These papers also show the norm which Holliday calls it Native-speakerism (2006, p. 385). He shows points and underpins them with references to evidences found in professional, cultural and ideological framework of teaching methodology in both western and non-western world. The paper native speakerism is particularly concerned about native and non-native debate and demands a fair and ideological construction of the latter, which is the main thesis of my interest. This article also mentions the term othering (Holliday, 2006,p. 385), and sheds light on both professional and intellectual fields, which stimulates further interest in my research. Furthermore, Holliday critiques the English language teaching methodology as he senses that it is based on Western-culture ideology. Holliday sees the native speaker has its over-arching iconic impact outside its demarcation in the non-western world as well though it primarily originates within English speaking education system. Holliday's assumption is true as it reflects on the non-western Hong Kong context-it is shown by John Lung that the Hong Kong Government schemes a plan to recruit three hundred native speaker teachers to teach at secondary schools in Hong Kong (1999, p. 1). It does not merely end here but this kind of scheme brings fatal mishap for native speaker teachers in Hong Kong as it jeopardises the jobs of the non-native teachers. Along with this, this paper emphatically mentions the terms liberalism in education and learner-centeredness used a means to conceal their attempt to correct learners' behaviour $(2006, \mathrm{p}$. 386). The second paper also focuses on the similar and conflicting ideas. It emphasises the traditional teaching pedagogy which requires native like proficiency and teaching of particular lexical category by which the identity of other cultures is lost. It also exposes the exploitation of other cultures through the spread of English in English language teaching. Finally, it demands the establishment of English as lingua franca and the role of its education is global rather than core-based where L1 variety dominates over other L2 varieties (Modiano, 2001, p. 344). Therefore, the debate stimulates an interest to investigate the findings amassed by Madiano and Holliday who do not provide any empirical manifestations to bolster their arguments. These two articles however expose the deeper thoughts of the researchers, which would serve as good criteria for further empirical study in this field to justify the arguments posed by them. These findings closely relates to the native and non-native teacher debate where my keen research interest lies.

\section{RESEARCH QUESTIONS}

While one of the papers is concerned mainly about the establishment of English as a lingua franca and fights for global recognition of non-native cultures and shows how the west managed to subordinate the cultures of learner communities across the globe, the other particularly focuses on how the west managed to subordinate the culture of learner community as well as how the English language teachers can actively function in the ecology of language by trying to recognise all cultural diversity and integrating them into learning. In the discussion, most of the points overlapeach other as the papers belong to the same context. Throughout these researches both Holliday and Modiano ask the following questions to investigate the term linguistic imperialism:

1. What are the major tools used to spread native culture, and how they are used?

2. What are the primary sources helping to promote native speaker culture and demote the non-native?

3. How the native-speakerism works in the field of ELT

4. What the ELT practitioners can and cannot do to restore the recognition of all English variety in the globe?

5. What would the end of the ecology of English if other varieties of English come in confrontations; would it lose its current prestige or any other language would dominate over it?

\section{DESCRIPTION OF THE ARTICLES}

This paper reviews two articles called Native Speaker Norms and International English and Native-speakerism, which are very meticulously chosen names and are highly revealing of the fact that 'English' which is today globally used for numerous purposes is also a subject of cultural and academic debate. The reason why is it so is often attributed to racial and cultural prejudices bearing in mind that English belongs to Britain, America 
and other English speaking countries. The first article sheds light on the Anglo-American culture-specific approaches to learning where the identity and virtual cultural integration of non-native teachers as well as students is endangered. This paper primarily suggests non-native teachers to use the opportunity of English language materials as tools to divert its negative effects by exposing its multiplicity of use as an international language other than teaching it only as EFL and ESL. The second article is the same more or less as it can be described as a replica of the major critiques of linguistic and cultural imperialism. It is also polemic about the surreptitious tools used to suppress the non-native cultures within teaching pedagogy.

As my research interest lies in the native and non-native teacher debate on as to whether native teacher is practically good or it is just an emotional impulse that makes us prejudiced towards the accent and pronunciation and colour of the British, and now the American as well, that stimulates our choice into native speaker teachers and discriminate the non-native, these two papers show intrinsic relevance in a number of issues, for instance, imperialism in practice, near native proficiency, the function of ELT practitioners are all significant factors to explore to justify if these factors matter in determining a good teacher of English. There is a historical debate over the fact that the native speaker is thought to be the source of all English, 'Linguistic theory has traditionally considered native speakers (NSs) as the only reliable source of linguistic data' (Chomsky 1965, in Moussu \& Llurda 2008,p. 315). There is similar evidence on discrimination shown by otherresearcher; they argue that 'thesocial recognition of NSTs and NNSTs is 'often judged on the basis of the speakers' accent' (Munro \& Derwing, 1994, p. 253-266). Conversely, this kind of prejudices to accents cannot provide any solid grounds on whether accent has any role to play at all in foreign language learning. This is one domain that has to be given attention with special empirical study both pedagogically and linguistically. It has to focus as well then on collect data on the progress of learning under native and non-native accent teachers and the intelligibility of non-native accents and their adverse effects, if any, in the process of mutual teaching environment.

To examine the first article, its major focus is on native-speakerism which shows all the scrambling of learning English and its adverse effects, for instance, the hegemony. Holliday agrees that the spring of all ideology in ELT is the native teachers who instills in the minds of students western culture (Holliday, 2005 in Holliday, 2006, p.385). Then he goes on quoting other researchers' technical terms used to show the native and non-native discrimination; Phillipson's (1992) trial to capture inequality, 'Centre' vs. 'Periphery' and Holliday's (1994) 'BENA' vs. 'TESF' which suffered from cultural overgeneralisation. It also sees that when the resistance to this adverse ideology throughout ELT is on gear, native-speakerism plays a complex iconic role outside and inside Europe. On the contrary, some like Jenifer Jenkins believe that the terms 'native and 'non-native' are unviable on linguistic grounds (Jenkins, 2000, p. 8-9 in Holliday, 2006, p.385). It is also shown further down in the same page of the article that how ideologies operate nicely and concealed from the view through $a$ nice field like TESOL which is obscured by liberalism in education system (Kubota, 2001, 2002 in Holliday, 2006, p.385). Holliday also mentions that,

The students and colleagues are considered as others when they fail to comprehend specific teaching and learning strategies constructed and packaged by the Western education policy as superior, for instance, 'active', 'collaborative' 'self-directed' and 'learner-centered' learning styles. So, these particular confining sets of styles implies to the emergence of binary oppositions which are of course 'inactive', 'non-collaborative' etc. which automatically categorise themselves as non-native styles of teaching. Holliday also mentions these are nativespeakeristic as they negatively labels the non-natives as 'collectivist' 'indirect' and 'passive', 'traditional' and 'undemocratic' (Holliday, 2006).

This cultural reduction is seen as chauvinistic narrative of Orientalism (Said, 1978 in Holliday, 2006). One of the foremost criticisms is delivered by Anderson who views that the 'close monitoring', 'learner training' and precise methodological staging can be seen as hiding a subtle agenda aimed at correcting non-nativespeaker 
culture (Anderson, 2005 in Holliday, 2006, p.386). Holliday also believes that it can also be traced back to the behaviourists' lockstep of the structural or audio-lingual approach (Holliday, 2005, p. 9 in Holliday, 2006, p. 386).

The article Linguistic imperialism, cultural integrity, and EIL primarily focuses on how to integrate the non-native cultures into learning as non-native culture is losing its entity in ELT. So, this article demands certain steps, for instance, the ELT practitioners to be aware of the means used in the ELT by native-educational enterprises and publishing companies. Some of the major means are often made accessible through the non-native teachers as well. Modiano points out,

When a practitioner explains to students that one linguistic variety is superior to, as is the case when proponents of $\mathrm{BrE}$ or AmE, for example, instil in the minds of the students the idea that other varieties are less valued, such practices interject into the ELT activity systems of exclusion which marginalise the speakers of other varieties (2001, p.339).

This is the most vital comment in this article. He also points out this can happen at lexical level when students are given only one variety instead of providing other equivalent varieties they think one lexical register is more useful than others in the domains. Modiano suggests the ELT practitioners to try using multiplicity of variety in the classroom instead of being an agent for supplying only the dominant cultural varieties (2001, p.340). Then he puts the limitation in the work of ELT practitioners that they cannot control the use of any varieties outside classroom ambience. He blames government agencies and private enterprises for exporting such educational materials by which they keep up the 'sphere of influence' constant. BrajKachru proposes that one way to safeguard the varieties is to use all indigenised forms of English (1982 in Modiano, 2001, p.340). Again, when David Graddol (1997) is doubtful about Kachru's inner circle's hold, John Honey prescribes a 'standard English' to promote and educate the 'disenfranchised' to partake in the discourses which will lead them 'forward' (1997 in Modiano:2001, p.342). Finally, it shows how the growing spread of technology that jeopardize Pennycook's plan to promote English as lingua franca and English now continues to colonise hundreds of thousands of hearts of non-native speakers, where a standard variety is equally doomed to fail (Madiano, 1999b in Madiano, 2001, p.342). In short, it blames the teachers who teach the core varietyas standard instead of teaching their students most varieties possible. It presupposes that the ELT practitioners can minimise the growth of one variety by taking a macro approach to teaching (Modiano, 2001:340).

\section{Type of Research}

These researches are based on other researches done by other researchers in the same field. There is no empirical evidence of the facts shown and justified. All the comments provided are made by famous linguists like Kachru, Graddol, Holliday who have contributed a good number of papers in the field of linguistics and ELT that helped promote the sense and awareness of ELT academics. These provide personal commentaries of researchers which agree and disagree on so many things.

\section{Methodology}

In this paper the methodology and method has been discussed interchangeably. In both the papers, Holliday and Madiano talk about the linguistic imperialism and the effects of imperialism. They also provide proper evidence for the fact why and how the Western culture dominates over other non-native cultures and how and why nonnative cultures are being underscored in the education enterprises. Both the researchers show that this is the ELT practitioners and government and private companies who are responsible for such happenings as they deal with teaching and materials (Holliday, 2006, p.385 \&Madiano, 2001, p.344). Holliday also presents comments on how western culture has used TESOL as a means to use native-speaker prejudice and he mentions the liberal education and methodological staging are the tools used to correct the non-native learners. Mandiano shows the effect of globalisation and what famous researchers like John Honey and Pennycook strive to pursue their mission to retain a Standard English variety and how their plan fails because of increasing use of technological 
access to different varieties of English (2001, p.342). Finally, Holliday and Madiano come to a solution that the ELT practitioners and English users in profession fields should try to integrate their own varieties into learning and professional activities, as Holliday mentions the dominant professional discourse must be avoided for better understanding and communication among speakers from other varieties (2005, in Holliday, 2006, p.386). But, it is demonstrated that the expansion of English is still very steady and English will still dominate as an important language on economic and cultural platform along with Spanish and Chinese (Graddol, 1997, p.3 in Madiano, 2001, p.344). So, the researchers do not show any particular method of collecting data as there is no numerical data presented. Most of the statements need a quantitative study to show evidence for how much the ELT practitioners use the 'core variety' and how they teach to their students. It is also significant to investigate what the students think about a particular standard of English and using particular register as superior. These papers could have been more reliable if they had provided 'interviews' and 'questionnaire' and 'numerical findings' on the basis of what the researchers say. For example, there is no particular evidence on the point that the TESOL and its methodological staging are used to correct the non-native cultures. This is invalid to say that learner-centred teaching is intended to show cultural superiority. A good empirical study can be done to investigate whether 'learner centred' learning works better or not. From my personal teaching experience I have found that learner-centred learning yields far more outcomes than teacher centred learning. But, it can still be justified through a qualitative and quantitative research how these assumptions work.

\section{EVALUATION OF THE RESEARCH}

The articles deal with almost the same topic and which has amassed some of the most vital and controversial issues in the history and politics. Since the British colonisation many books have been composed and since then the non-native speakers like Edward Said and Noam Chomsky have opposed the hegemony of English through their writings. Edward Said's Orientalism in 1978 delineates how Western and American culture played roles through education to erode non-native cultures from gaining status, and Said views the terms 'undemocratic', 'easily-dominated' 'traditional', the opposites of which the West instils into learning of non-native speakers, as Chauvinistic narrative of Orientalism (1978 in Holliday, 2006, p.185). Pennycook's mention of Robinson Crusoe's civilising man Holiday implies native-speakerists' moral mission to bring superior culture and education to nonnative speakers who are thought to be unable to succeed on their own terms (1998, p.10-16, in Holliday, 2006, p.385). Along with this, similar comments are made by other researchers who show how non-native teachers are discriminated in the academia, for instance, '....If the speaker's accent is different from the listener's, and this listener cannot recognize it as any other 'established' accent, the speaker will be placed within the non-native speaker category' (Munro \& Derwing, 1994, p.253-266).But it is shown that non-native speakers can excel in performance in teaching and learning English. Phillipson puts a straight argument that:

Since most NNSs had learned their second language as adults, they were better equipped to teach the L2 to other adults than those who had learned it as their L1 when they were children (1992)

Now, it is questionable that if researchers think that non-native speakers can be better teacher and speaker, why should they follow the so called 'core variety' and why native speaker should correct them and consider them unable to succeed on their own terms. It can be said clearly that the attempt to set one Standard by Honey and Pennycook is quite divisive as they do not clarify their motif; they only put that one standard will help and empower non-native speaker to function in the discourses which will ultimately lead them forward. This word forward can be very ambiguous and may have a negative meaning and one may question will it not lead them to becoming the agent of native-speakersim? On the other hand, conservatives would say disenfranchised should learn it to acquire wealth (Modiano, 2001, p.342). Therefore, there are many issues which are highly conflicting and which have to be measured on the research scale, through qualitative and quantitative. Most of the implications are not wrong in many senses as some schemes like methodological staging triggers questions in minds why should a methodology follow specific and regular staging. 


\section{IMPLICATIONS}

The review of the articles provides further implications to the cultural and political prejudices towards native speaker and native-speaker cultures. This review yields more hypotheses on the issue, native and non-native teachers' debate and it serves as a good reflection of the valuable thoughts which are consequences of valid reasons like cultural domination, cultural indoctrination, and cultural tools used to lock the souls of non-natives such as ELT methodology and different English language teaching courses like TESOL and liberalism in education. The review also finds the ELT teachers can play as native-speaker agents unknowingly or knowingly by teaching one specific lexical and phonological variety to their students. Also, the claims that liberal and learner-focused learning and close monitoring are secretive means used to correct non-native culture can be a very good area to take hard look at. Above all, the unending rivalry between native and non-native is worth paying proper attention to justify the equality and inequality between native and non-native teachers and learners.

\section{CONCLUSION}

The article shows that the integration of culture only need careful attention of the ELT practitioners who can integrate diverse culture and can teach equivalents to standard variety instead of being and agent of nativespeakerists. The implications of cultural hegemony require further empirical study to motivate all non-native speakers into accepting and using English as a lingua franca. Teachers cannot always be blamed as they do not hold power or authority of prescribing text book materials. The teachers can teach all the varieties in class and instill in the minds of the pupils that no specific variety is superior. However, one standard variety should be learnt in the academia as one standard variety is needed in various purposes and it is not possible to comprehend all different varieties at the same time. So, for mutual intelligibility a particular set or model can be suggested but other varieties have to be recognised as they are also used as communicative medium. In other words, a qualitative and quantitative research has to be conducted to dissolve the debate over standard lexical and phonological varieties which are the two fundamental factors that discriminate native from non-native speakers.

\section{REFERENCES}

1. Holliday, A. (2006). Native-speakerism. ELT Journal, 60(4), 385-387.

2. Jenkins, J. (2000). The Phonology of English as an International Language (1st ed.). Oxford: Oxford University Press.

3. M, M. (2001). Linguistic imperialism, cultural integrity, and EIL. ELT Journal, 55(4), 339-347.

4. Moussu, L. \& Llurda, E. (2008). Non-native English-speaking English language teachers: History and research. Language Teaching, 41(3), 315-348.

5. Munro, M., \& Tracey M. Derwing, T. (november 1,1994).Evaluations of foreign accent in extemporaneous and read material. SAGE Journals, 11(3), 253-266.

Citation: Md Nurul Anwar, "Linguistic Imperialism \& Cultural Politics in English Language Teaching World" American Research Journal of English and Literature, vol 4, no. 1, 2018, pp. 1-6.

Copyright (c) 2018 Md Nurul Anwar, This is an open access article distributed under the Creative Commons Attribution License, which permits unrestricted use, distribution, and reproduction in any medium, provided the original work is properly cited. 